\title{
Arabic as a Foreign Language: Phonological Analysis of Speech Sounds Produced by Students
}

\author{
Awad H. Alshehri ${ }^{1}$ \\ ${ }^{1}$ Department of English, College of Languages and Translation, IMSIU, Riyadh, Saudi Arabia \\ Correspondence: Awad H. Alshehri, Department of English, College of Languages and Translation, IMSIU, \\ Riyadh, Saudi Arabia.
}

Received: March 24, 2021

Accepted: July 21, 2021

Online Published: July 27, 2021

doi: 10.5539/elt.v14n8p47

URL: https://doi.org/10.5539/elt.v14n8p47

\begin{abstract}
The aim of this paper is to expose the potential difficulties encountered by students learning Arabic as a foreign language (AFL) with a focus on sounds production. The research design was descriptive-analytic. The data was obtained using direct recording and interviews. The sample included 27 AFL students at the Arabic Institutes at IMSIU and KSU. The work on this research is twofold: first, the paper reports on teachers' and learners' views on the general difficulties encountered by students learning Arabic, focusing on those in post-secondary school getting ready for tertiary education. Secondly, the paper analyzes their speech for pronunciation errors found in sounds production. The results show that learners generally had no problem expressing themselves, but they had some pronunciation issues with some specific Arabic sounds. The results also show that the students attempt different methods to overcome pronunciation difficulties. Teachers were aware of these difficulties, and they had their own methods to help improve students' pronunciation of unfamiliar sounds. The findings show that traditional ways of teaching Arabic sounds are not enough, and difficulties could still exist, as shown by the phonological analysis of sounds environments. The study suggests that implementing an eclectic approach, leveraging the use of technology, could help AFLs to improve their pronunciation.
\end{abstract}

Keywords: AFL, CPH, eclectic, KSU, SLA, IMSIU

\section{Introduction}

In this paper, the acronym AFL refers to Arabic as a foreign language, whose sounds may pose some difficulty to AFL students. AFL teachers may also sense the difficulty their students encounter in learning some Arabic sounds and may find teaching these sounds quite cumbersome. They would attempt to find ways to help them overcome any difficulty met. When talking about Arabic sounds, we have in mind some sounds that are very similar in their

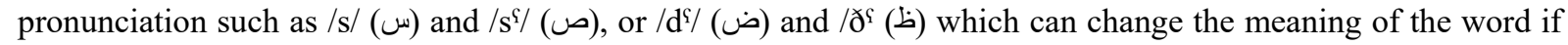
mispronounced, thus impeding communication. These are just examples. There are other sounds that can impede communication, too. These issues could be attributed to certain factors that can stand in the way of producing these sounds, such as age, mother tongue, and teaching and learning methods. New technology and the use of digital dictionaries may help facilitate learning these sounds and mastering their pronunciation. Looking at the study conducted by Hamad (2018), the researcher concluded that using different techniques in teaching Arabic to AFLs could make teaching more effective and could contribute to facilitating learning and motivating students. Hamad adds that the use of technology could develop students' abilities to communicate more effectively. In the current study, there is an investigation and analysis of the problematic sounds met by AFL students, the teaching methods implemented and suggested by the teachers, and the learning methods adopted by the students.

\subsection{Purpose of the Study}

The purpose of this study has three parts. The first is to find out how students conceive Arabic sounds and what difficulties they encounter. The second is concerned about the teaching and learning methods of Arabic sounds. Third, and most important, is to analyze students' speech phonologically to determine what sounds are not pronounced well and what sounds are mixed with other sounds. Therefore, the study will analyze students' speech sounds for irregular and unusual pronunciations. This analysis will attempt to count for these errors in pronunciation using phonological analysis. 


\subsection{Significance of the Study}

Speech sounds are significant for any language learner, and oral communication depends mostly on how sounds are produced and perceived. Any mispronunciation of speech sounds may well interfere with streamlined communication and could impede understanding. Not all sounds are cumbersome and challenging to learn. The same applies to AFL students at Arabic Language Institutes. They encounter some problems. Therefore, pinpointing the sounds that are most likely difficult to learn is what this study attempted to do. Finding ways around these sounds should help teach and learn difficult Arabic sounds, and the analysis of sounds environments can also help in solving pronunciation issues.

\subsection{Research Questions}

The study attempts to answer the following questions:

1) What problems do AFL students have when pronouncing Arabic sounds?

2) What teaching methods are followed by AFL teachers in Saudi tertiary classes?

3) What learning methods are followed by AFL learners to develop their sounds production?

\subsection{Determinants of the Study}

1) Scope and Delimitation: The topic of the study was limited to sounds of Arabic, as pronounced by AFL students at Arabic Language Institutes in Riyadh, Saudi Arabic.

2) Time-Limit: The period under consideration is from September to October 2020.

\section{Literature Review}

Language classes are usually taught using books designed specifically for the purpose of teaching the target language as a foreign or second language. These books are expected to include helpful and user-friendly material that suit both teachers and learners. For example, books written for teaching English as a foreign or second language usually provide appropriate information on the pronunciation of sounds and words in teacher-oriented materials (Bailey \& Nunan, 2005). These books do undoubtedly include other aspects of the language such as vocabulary and sentence structure in addition to the treatment of other skills such as listening, speaking, reading and writing.

Pronunciation-wise, English language teachers can utilize conventionalized symbols (called IPA) to help students pronounce the 44 sounds of English, which can be of positive influence on EFL students as observed during a couple of years of teaching English. However, the use of these symbols is considered by some authors, such as Paikeday (1993), as unimportant and almost useless. On the other hand, dealing with sounds symbols are considered by language scholars such as (McMullan, 1988; Newton, 1999; Tench, 1992) as significant to language learners and could enhance their pronunciation. Therefore, language teachers may feel torn between the use or non-use of IPA symbols, and their decision can be influenced by their background as language learners and also by the aims of the course they teach, its material and description (Mompean, 2015).

The teaching of foreign languages, as Jabbarova (2020) mentioned, gives some weight to the phonetics of the target language. She adds that producing a description of the phonetic system of the first language and making a comparative analysis with the target language can help find correspondences between the two. This can, in turn, help in learning the new sounds that may impose some difficulty for L2 learners.

Research on pronunciation has witnessed a good upsurge lately, as explained by Pennington (2021). She clarified that there was a positive sign of an increase in L2 pronunciation research. Another good sign, she added, was the robust improvement of pronunciation teaching and research based on SLA theories and previous studies on pronunciation.

Arabicwise, and as long as pronunciation is concerned, AFL students appeared to have some difficulties in

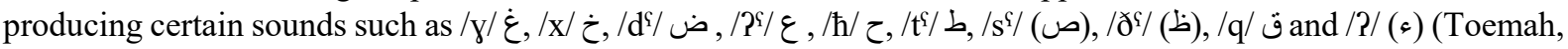
1982). These sounds are absent from the students' mother tongue. In addition, some of these sounds have counterparts in Arabic, which could aggravate the problem and lead to more difficulty and confusion.

\subsection{Factors Affecting Pronunciation}

Among the factors that could influence language learning, as mentioned in the introduction, is learners' interest and aspiration, which could have a strong impact on their pronunciation, whether or not they are keen to sound normal or at least close to how native speakers sound. However, some language learners may be more interested in being understood than being native-like, as shown by a study on EFL learners by Tergujeff (2012). The subjects in her 
study wished more to speak fluently and intelligibly than to sound like a native speaker. In this regard, Celce-Murcia, Brinton, and Goodwin (1996) believe that there is a threshold level for pronunciation for a speaker to be understood and for communication to be successful, and once that threshold is reached by the learners, language learners could communicate smoothly.

Study length and exposure to the language can be another factor that impacts learners' pronunciation. The longer the exposure is, the more they wish to have intelligible pronunciation. Students at the beginner level may not be as interested in pronunciation as those at the tertiary level, as shown by a study conducted by Cenoz and Lecumberri (1999). Their study showed that learners at the tertiary level were more concerned about aspects such as stress and intonation, where segmentals and suprasegmentals play a role.

Another factor that could influence learners' pronunciation is their age when learning the target language. Talking about age brings us to what is called the Critical Period Hypothesis (CPH), which is said to play a significant role in pronunciation. Language teaching has witnessed significant improvements over the past 50 years, specifically pronunciation. In this regard, pronunciation is argued to be acquired at an early age and not taught, which implies that pronunciation is supposed to be a skill direct instruction does no serve. This argument is grounded in the $\mathrm{CPH}$, which says it is difficult to acquire a native accent when learning a language after the age of puberty (S. D. Krashen, Long, \& Scarcella, 1979). However, this claim is disputed by the fact that there are cases where language learners have acquired native-like accent after puberty age, which to some extent weakened Krashen's CPH.

\subsection{Listening and Pronunciation}

There seems to be a strong connection between pronunciation and listening, and some would give it a priority over listening activities in terms of which one to focus on first. In a study conducted by Damiati (2005) on the correlation between listening skills and pronunciation accuracy, she found that there was a positive correlation between the two. She also suggested that it would be difficult for learners to understand spoken material if they could not perceive the correct pronunciation of the word and sentences in the activities. The research also concluded there was also a mutual relationship between the two, meaning that perception of spoken material is essential for succeeding in the listening activities, and at the same time, listening activities could reflect positively on students' pronunciation. Nunan (2002) refers to the listening skill as a sister to speaking and believes that that emphasis on oral skills gives listening a boost in language teaching. Nunan adds that listening was emphasized by Krashen's (1982) Comprehensible Input and by Asher's (1988) Total Physical Response. Listening continued to gain more importance in language learning literature. Renukadevi (2014) believes that listening is a basic skill for all other language skills, and since this skill is intervened in each skill, he believes there is a need for making innovations in the teaching and learning of listening.

\subsection{Pronunciation Developmental Stages}

For learning a language, be it first or second, there seem to be specific developmental sequences, which represent a common phenomenon (Wahba, Taha, \& England, 2014). This sequence applies to different languages as well. Mansouri (2000) investigated the acquisition of Arabic negation through task-based activities and found out that there was a progression of some type in using the words /la:/ (don't, doesn't) $\rightarrow / \mathrm{lam} /(\mathrm{didn}$ 't) $\rightarrow / \mathrm{lan} /($ won't $) \rightarrow$ /laysa/ (not), where learning of each one of these words progressed with the learning of different tense. Language Learning Paradigm, as explained by Wahba et al. (2014), benefits from the input/interaction/output hypothesis. It is a common approach to language learning, which begins with the premise that conversation and negotiation are useful tools for language learning. In this type of negotiation, correction, feedback and learning will take place. The example from Gass and Varonis (1989) where a learner tries to give a description of a picture so that the other one can draw it is a representative example of a negotiation that takes place in a conversation where corrective feedback takes place. That type of dyad, as explained by Gass and Varonis, is more effective if it takes place between native and nonnative speakers.

\subsection{Teaching and Learning}

Methodologies for pronunciation teaching, however, have developed, and instead of emphasizing single discrete sounds, the attention moved to much broader communicative aspects (Jones, 1997). However, he says that despite these changes, teaching methods still concentrate on the behavioristic model where the primary medium includes imitation and discrimination drills. Nonetheless, pronunciation teaching based on communicative competence is considered significant for spoken discourse, which includes meaningful suprasegmental features (Brazil \& Coulthard, 1980).

Yaakub (2007) recommended that using the appropriate methods, such as the keyword method, was essential in the language teaching and learning process. This study proved that the keyword method could succeed in 
facilitating vocabulary learning among Arabic learners. To apply this method effectively, the researcher suggested that the learning group should be close in terms of the academic background, their memorization power should be identified, and the learning environment should be conducive.

Pronunciation-wise, Oxford (2016) designed a Strategy Inventory for Language Learning (SILL). And as far as pronunciation is concerned, she suggested certain strategies for improving L2 pronunciation. She started with the idea of connecting the sound of a new word with an image or picture. Other strategies she suggested included using rhymes, acting out the new words, repetition of the sounds, using words in conversation, listening to and watching SL material on TV, loud reading, paying attention to the NS pronunciation, talking with NS, having clear goals and monitoring the progress, and asking for a correction.

With all that being said and discussed, this paper focuses on Arabic learning for AFL students and investigates the difficulties and methodology from the teachers and students' viewpoints.

\section{Methodology}

This research was designed to be analytic descriptive. The paper examined speech sounds made by AFL students at two Arabic institutes in Riyadh to find out what pronunciation problems they had and what learning strategies they followed. It also examined teachers' viewpoints on teaching and learning strategies in the AFL context, what challenges they encountered and how they responded to those challenges.

\subsection{Participants}

The participants in this study were Arabic language learners studying in two Arabic institutes in Riyadh in two different universities, IMSIU and KSU. There were also AFL teachers at the same institutes. The first sample included male students who finished or about to finish their Diploma in Arabic. The total number who gave their consent to participate in the study was eighteen students. Their mother tongue was not Arabic. All participants had taken courses designed for AFLs, and their ages ranged from 20-30 years old. Their educational background was taken into account to give justifications for any variations that might take place. The teachers who participated were AFL teachers whose mother tongue is Arabic, holding an MA or PhD in Arabic. They had ample experience with teaching Arabic to non-Arabic-speaking students.

\subsection{Instrument}

The first instrument employed in the study was recordings since the study focused on the analysis of the speech made by the participants in reply to a number of questions whose answers were two-fold: first, information about the students, second, speech analysis. Another instrument used was an analysis of the participants' recitation of the first Surah in the Holy Quran, Al-Fatiha. This Surah was selected intentionally because it would be read in every Rakah in the Muslims' prayer, and the participants were expected not to have problems with the Arabic sounds in any of the Surah verses. Therefore, the study has more tendency towards being descriptive-analytic. The second instrument was an interview with the AFL teachers at the Arabic Institute, whose responses were analyzed qualitatively. Every one of them would answer the same questions but was expected to reflect his own experience with the students in terms of teaching, learning and the difficulties encountered with a focus on pronunciation. The interview questions covered teachers standpoints on AFL teaching methods, their suggestions for AFLs to improve their pronunciation.

\subsection{Data Collection and Analysis}

The researcher contacted a number of participants and told them that the recordings would be used for research purposes only and would be kept strictly confidential and destroyed afterwards. The participants had the choice of whether to continue in the study and do the recordings or withdraw. The recordings were collected and sent using WhatsApp by the student himself denoting his absolute consent. The recordings were dealt with in two ways. First, the transcript was written for qualitative analysis. Second, the speech sounds were analyzed for sounds that would deviate from the normal pronunciation of Arabic and which an Arabic native speaker would consider ill-formed. The teachers' interview was analyzed qualitatively, and then connections and associations were made between what the students said, what the teachers thought, and what the speech analysis revealed.

\section{Presentation of Results}

The number of teachers was 21 from 2 Arabic Language Institutes solely established for learners of Arabic as a foreign language, and the number of AFL students was 27 from the two institutes. 


\subsection{Teachers Responses}

\subsubsection{Statistics}

The results show that most of the teachers were highly qualified and their qualifications included Bachelors, Masters and $\mathrm{PhD}$, with $\mathrm{PhD}$ holders representing $65 \%$ of the respondents.

Table 1. Teachers' Qualification

\begin{tabular}{lll}
\hline $\mathrm{PhD}$ & $\mathrm{MA}$ & $\mathrm{BA}$ \\
\hline $65 \%$ & $25 \%$ & $10 \%$ \\
\hline
\end{tabular}

Their teaching experience in teaching Arabic to Arabic- and non-Arabic speaking students appears to be adequate. Some taught for less than 5 years, some between six and ten years, and some more than ten years.

Table 2. Experience in Teaching AFL

\begin{tabular}{llllll}
\hline $1-5$ Years & \multicolumn{3}{c}{ 6-10 Years } & \multicolumn{2}{c}{ More than 10 Years } \\
\hline \multirow{2}{*}{ Arabic-Speaking } & $\begin{array}{l}\text { Non-Arabic } \\
\text { Speaking }\end{array}$ & Arabic-Speaking & $\begin{array}{l}\text { Non-Arabic } \\
\text { Speaking }\end{array}$ & Arabic-Speaking & $\begin{array}{l}\text { Non-Arabic } \\
\text { Speaking }\end{array}$ \\
& $30 \%$ & $5 \%$ & $30 \%$ & $20 \%$ & $40 \%$ \\
\hline
\end{tabular}

Regarding training on teaching Arabic to non-Arabic speaking students, most of them had some training programs on teaching Arabic to non-Arabic speaking students.

Table 3. AFL Training Program

\begin{tabular}{lll}
\hline No Training & $1-4$ Training Programs & More Than 4 Training Programs \\
\hline $10 \%$ & $45 \%$ & $45 \%$ \\
\hline
\end{tabular}

\subsubsection{Teaching Methods}

Teachers responses were classified into different themes such as repetitions, reading, direct approach and other themes.

Repetition seems to be the one method that teachers preferred when teaching the sounds of the Arabic alphabet. Some respondents said they would make the student repeat after listening to the correct pronunciation, as well as repeating the words that have similar sounds. Repetition appears again in the responses of some respondents who suggested mimicry and simulation as useful techniques. These techniques have the aspect of repetition after listening to the sounds or words.

The Oral-Auditory approach has been mentioned several times by the respondents, and although this approach was basically for teaching children with hearing problems, the teachers used the term to mean integrating the spoken language with focused listening. It can be described as a direct method for teaching the sounds of the language. The idea of listening appeared a couple of times in the responses.

Total/Partial Approaches appeared in the responses as effective for teaching the Arabic phonemes, and which the teachers used in teaching pronunciation of Arabic sounds. Although each of the approaches, as one teacher explained, has its own advantages and criticism, mixing the two could be an option for the teacher when teaching the sounds of the language. What the teachers meant by Partial Approach was the teaching of sounds in isolation first with a focus on problematic sounds that do not exist in the students' mother tongue, in addition to similar sounds that the student did not differentiate such as $/ \mathrm{s} /$ and $/ \mathrm{s}^{\mathrm{q}} /, / \mathrm{s} /$ and $/ \mathrm{z} /$, and a few more. The Total Approach, as explained by the teachers, was the introduction of the sounds in real, meaningful words, preferably introduced using minimal pairs such as /sædə/ (become a governor), /zædə/ (increased) and / $\mathbf{s}^{\mathrm{f}}$ ædə/ (hunted or caught). The Total Approach can extend from single words to phrases and short sentences, as the teachers confirmed. Another respondent agreed with this, saying pronunciation can be dealt with partially then holistically.

The Audio-Visual Method was seen as an option that some teachers brought up. This method focuses on the students seeing the written form of the sound. The teachers explained that the use of this method would create a mental association where the audible sound is connected with the shape of the sound, preferably accompanied by a picture of the object being talked about.

The Communicative Approach is also suggested by some of the respondents as a palpable approach where the students would communicate with native speakers of Arabic. They looked at this as an incentive for the students to try to pronounce well in a way that would make them more comprehensible, in addition to learning from native speakers. Thus, overcoming some pronunciation problems. 
Minimal pairs were mentioned as a technique for teaching pronunciation of similar sounds, emphasizing what some teachers said as to teaching similar sounds. They seemed to have the same minimal pairs mentioned above; as /sædə/ and /zædə/. However, some teachers divided minimal pairs into major and minor. Major minimal pairs include the sounds with the same place of articulation such as $/ \mathrm{k} / \mathrm{and} / \mathrm{g} /$. Both are velars. Minor minimal pairs include the sounds that are similar but have different places of articulation such as $/ \mathrm{t} /$ and $/ \mathrm{t} \mathrm{s}$.

The Combinatorial Method (or Eclectic Approach) was mentioned by many teachers, suggesting that selecting one way for teaching the problematic Arabic sound would not suffice. Rather, they would use a number of methods and approaches to teaching pronunciation and other language skills such as grammar, listening, reading and writing. Reading, as some of them explained, start with recognition, pronunciation, understanding, and criticism. Using this approach, the teacher could benefit from different teaching methods to transform the learner from mere pronunciation to higher skills such as comprehension, analysis, application and evaluation of the oral and written texts.

Acting was mentioned by some of the teachers as a way for teaching the pronunciation of Arabic sounds together with videos. Acting or role-play, as they explained, could offer learners a chance to practice the language in a fun way. It is a form of application and practice which learners need in language classes.

\subsubsection{Difficult Sounds from Teachers' Viewpoint}

The respondents were requested to identify the sounds that AFL students faced when learning Arabic. They were also asked to arrange these sounds according to their level of difficulty, starting with the most difficult, depending on the teacher's observation. The teachers agreed that the sounds that were absent from learners' first language could, in most cases, pose a problem for them and would take them a long time to approach satisfactory pronunciation that would not deviate from the normal, acceptable production. All of them agreed that glottal sounds were the most difficult for AFLs. The following table shows the problematic sounds starting with the least to the most difficult.

Table 4. Difficult Sounds from Teachers' Viewpoint

\begin{tabular}{|c|c|c|c|c|c|}
\hline Sound No & Sound symbol & Arabic sound & Times Mentioned & Sound symbol & Arabic sound \\
\hline 1 & $/ \theta /$ & $\dot{H}$ & 9 & $/ \mathrm{y} /$ & $\dot{\varepsilon}$ \\
\hline 2 & $/ \mathrm{s} /$ & س س & 10 & $\mid \mathrm{x} /$ & $\dot{\tau}$ \\
\hline 3 & $/ \mathrm{r} /$ & ر & 11 & $/ \mathrm{d}^{\mathrm{s} /}$ & 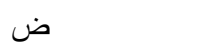 \\
\hline 4 & $/ \mathrm{t}^{\mathrm{f}} /$ & b & 12 & $/ \mathrm{P}^{\S} /$ & $\varepsilon$ \\
\hline 5 & $/ \mathrm{s}^{\mathrm{\varsigma}} /$ & ص & 13 & $/ \mathrm{h} /$ & $\tau$ \\
\hline 6 & $/ \partial^{\varsigma} /$ & ظ & 14 & & \\
\hline 7 & $/ \mathrm{q} /$ & ق & & & \\
\hline 8 & $/ \mathrm{P} /$ & 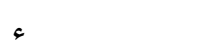 & & & \\
\hline
\end{tabular}

From the teachers viewpoint, the least difficult sound AFL would face were $/ \theta /, / \mathrm{s} / \mathrm{and} / \mathrm{r} /$ as in the words

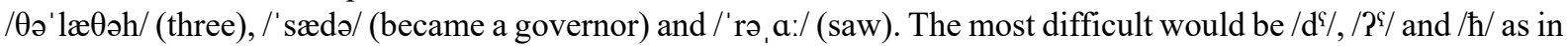

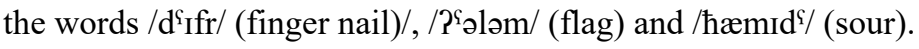

\subsubsection{Teachers' Suggestions for AFL Students}

The teachers suggested repetition and simulation as advisable methods for improving students' pronunciation. In addition, some of the teachers believed that careful listening to model pronunciation must precede repetition and simulation. Another related source or model that was suggested was YouTube videos. These sources can be used with all problematic Arabic sounds for AFL learners. One of the practices suggested by the respondents was direct repetition after the teacher in the classroom, where they would keep drilling at their own time until they master the sound. This happens by highlighting the problematic sound or sounds in the words and how they would be distinguished from similar sounds. Another source of listening, as suggested by some, was the Holy Quran recited with elocution rules, which emphasizes places of articulation and extends to some phonological processes, too. Related to the model pronunciation, some teachers suggested involving learners in an environment where Standard Arabic was the medium, such as podcasts and media broadcasting in Arabic, including the Holy Quran.

Another suggestion was related to the teachers' practices discussed earlier, which was the use of minimal pairs in context, as in the words /sædə/ (became a governor) and/zædə/ (increased). Another example brought up by the

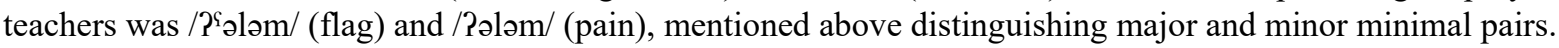


Different from this, some believed that pronouncing words in isolation until an acceptable degree of mastery could precede pronouncing them in words or sentences. Similar to this was the pronunciation of difficult sounds using the Arabic vowels and diacritics, long and short ones. For example, the sound $/ \Upsilon^{\S} /$, being a difficult sound for AFL

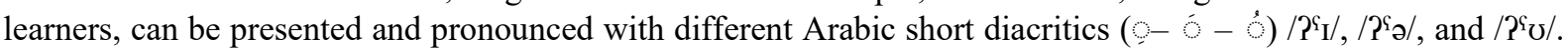

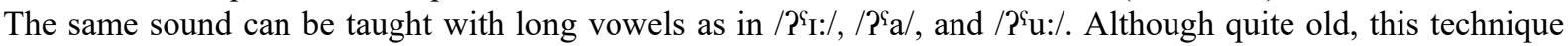
appears to be still common and accepted.

Visual illustration of sound production was another suggested practice that could be, as the teacher believed, effective in teaching pronunciation. Here, the place of articulation is focused upon and should be clear to the learners. It is a technique for focusing students' attention on sound production organs and how to utilize them in learning the production of difficult sounds.

The idea of contrastive studies between the Arabic and the student's mother tongue was brought up in the teachers' responses. They believed that this should direct students' attention to the sounds which they would need to focus on, and which in turn would help them advance faster in learning the production of difficult sounds.

However, and quite surprisingly, a few participants looked at pronunciation as a natural problem that was beyond solution. Therefore, eschewal of pronunciation treatment was what they suggested doing, believing that having comprehensible pronunciation would suffice as long as the students were understood by others.

\subsection{Students' Responses}

The students did two successive tasks on the recordings. First, they answered some questions about their Arabic learning experience. Second, they recited the first Surah in the Quran, Al-Fatiha. Below is the analysis of each part.

\subsubsection{Students' Responses}

The results showed that all the respondents were not born and educated in an Arabic speaking country. Their education varied since some started studying Arabic and Quran in their non-Arabic speaking countries, and then they came to the Arabic Institute to learn Arabic, which was a requirement for pursuing their undergraduate and/or postgraduate studies. When asked about the most difficult Arabic sounds they encountered, they agreed on some sounds, while some sounds were only difficult to some individuals. The table below shows that the most difficult sound they encountered was the voiced velar fricative $/ \mathrm{\gamma} /(\dot{\xi})$ as in the words / $\mathrm{\gamma} ə \mathrm{rr} \mathrm{b} /$ (stranger) and /'yədəb/ (anger). The second difficult sound was the voiced retroflex plosive /d/ (ض) as in the words /d`a' r:f/ (weak) and /berd ${ }^{\mathrm{S} /}$ (eggs). The third sound in difficulty was the voiceless retroflex dental fricative / / $/$ / (ל) as in the words

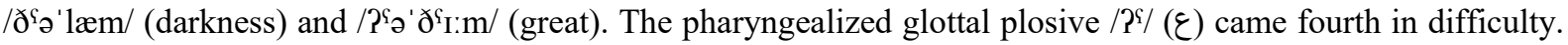
The words /' ? $^{\mathrm{e}} \mathrm{m} /$ (eye) and $/ \mathrm{ku}: \mathrm{P}^{\mathrm{f} /}$ (elbow) are examples where the sound occurs. Another less problematic sound was the voiceless post-alveolar pharyngealized fricative $/ \mathbf{s}^{\S} /(ص)$ found in words such as $/ s^{\varsigma} \partial^{\prime} \mathrm{dr}: \mathrm{q} /$ (friend) and $/ s^{\mathrm{s}} \mathrm{a}: \mathrm{r}$ / (became). The last sound the student saw as difficult was the voiced uvular plosive /q/ (ق) found in the words /'qəlb/ (heart) and /'næqəh/ (she-camel). The table below shows the difficult sounds where the density of the dots indicates the level of difficulty from the students' viewpoint.

Table 5. Difficult sounds from Students' Viewpoint

\begin{tabular}{|c|c|c|c|c|c|}
\hline & & ๑ & 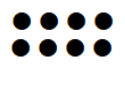 & 000 & $\bullet \bullet$ \\
\hline$/ \gamma / \dot{\varepsilon}$ & ض /d/ & ظ / / & $/ \mathrm{P}^{\mathrm{Y}} / \varepsilon$ & ص /S/ & ق /q/ \\
\hline
\end{tabular}

In response to what they did to improve their pronunciation and overcome the difficulties they encountered, they said it was normal for one to find difficulties if Arabic was not his/her native language, but they would need to train their tongue. Their learning methods varied, but most of them thought that repetition and loud reading was the most preferable and practical. Others said that, in addition to repetition and reading, they would listen to the Quran as a model pronunciation guide whose readers would take care of articulation of the sounds according to elocution rules. Some, however, added that they would practice with classmates and native speakers of Arabic.

Their advice to new AFL students was, to some extent, similar to their practices when they became involved in language learning. The first two things most of them suggested were loud reading and repetition. They thought that this was the best tongue-training practice for language learners. Some of them referred to listening to native speakers of Arabic reciting the Quran, reading the news and or making podcasts. They thought that those would be good pronunciation sources that they would imitate. 
Some of them thought beyond learning methods and touched upon some personal traits that the learner needs to have when learning the language. Among the things they suggested were patience, good intention and sincerity.

Language learning requires patience and perseverance since the job is not simple. It needs dedication and a good amount of work. Good intention is connected with the learner's aim. So, if the aim is clear and significant, the student would exert all efforts to reach those aims. The question of sincerity, as advised above, is connected with the student's intention, too. Are they learning the language just to get a job, or in response to what other people could have wanted? Or rather, are they learning the language because they truly wanted to learn? The answers to these questions could reveal the level of sincerity suggested above.

\subsubsection{Students' Speech Recitation Analysis}

Students recorded recitation of the first Surah in the Quran, Al-Fatiha, which was analyzed for pronunciation issues that they might have. The table below shows the difficult sounds where the density of the dots indicates the level of difficulty according to the analysis.

Table 6. Recitation Analysis

\begin{tabular}{cccc}
\hline & $\bullet \bullet \bullet \bullet$ & $\bullet \bullet \bullet \bullet \bullet$ \\
\hline $\mathrm{\gamma}(\dot{\varepsilon})$ & $P^{\varsigma}(\varepsilon)$ & $\bullet \bullet \bullet \bullet$ & \\
\hline
\end{tabular}

The results revealed a very interesting aspect that seemed worth investigating. The voiced velar fricative $/ y /(\dot{\varepsilon})$ in the verses was pronounced by the students correctly in the word /'year/ (except) while incorrectly in the word /mə' $\mathrm{d}^{\mathrm{f}} \mathrm{u}: \mathrm{bi} /$ (evoked anger). A similar case happened in the pronunciation of the pharyngealized glottal plosive

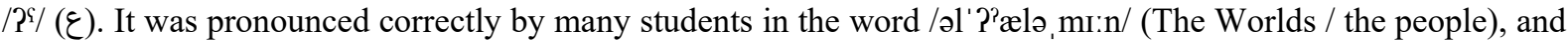

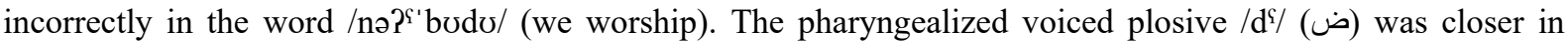
pronunciation to the plosive /d/ than the Arabic sound, and the voiceless post-alveolar pharyngealized fricative $/ \mathrm{s}^{\mathrm{S} /}$ (ص) was almost the same as the voiceless alveolar fricative /s/. Pharyngealization of the /s/ and /d/ seemed too difficult for the students or they might not have noticed the difference.

\section{Discussion}

\subsection{Difficult Sounds for AFL Students}

In reply to the first question of the study related to the problems AFL students have when pronouncing Arabic sounds, the results showed that there was some agreement or crossover between what the teachers noticed, what the students knew, and what the speech analysis revealed. The sounds were $/ t^{\S} /(b), / s^{\varsigma} /(ص), / \mathrm{C}^{\varsigma} /(ظ), / q /(r), / R /(\varepsilon)$,

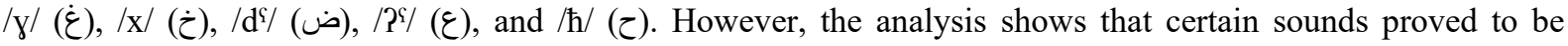
problematic and deserve more investigation and justification. Those sounds are all pharyngealized. It was no surprise since these results echo what (Howatt \& Widdowson, 2004) said about the inevitability of mispronunciation in any $2^{\text {nd }}$ language classroom.

The first and most challenging sound / $/ \mathrm{\gamma} /(\dot{\varepsilon})$, as the analysis shows, is confused up with the /q/ (ق) sound. The words /yo'rı:b/ (stranger) and /qa'rı:b/ (near) appear to be easily mixed up. The most interesting aspect the analysis shows is that the sound $/ \mathrm{\gamma} /$ is sometimes pronounced correctly and sometimes incorrectly. This requires a study of the environment where the sound occurs. Studying the environment where the sound appears in these two words /'year/ and /mo'yd'u:bi/. In the second word, the / $\mathrm{\gamma} /$ was pronounced as /q/. We can deduce that /y/ is easy to pronounce when followed by a vowel and difficult when followed by another consonant or found in a consonant cluster, where it is pronounced as /q/. This can be represented phonologically as follows:

$$
\begin{aligned}
& / \mathrm{y} / \quad \text { [y] } / \longrightarrow\left[\begin{array}{l}
\mathrm{V} \\
\end{array}\right] \\
& / \mathrm{\gamma} / \mathrm{q}] \quad \rightarrow-\left[\begin{array}{l}
\mathrm{C} \\
\end{array}\right]
\end{aligned}
$$




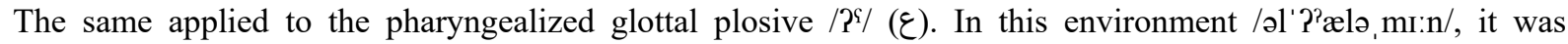
pronounced correctly but incorrectly in the /nə? ' 'bodo/ environment, where it was pronounced closer to the glottal stop $/$ ?/.

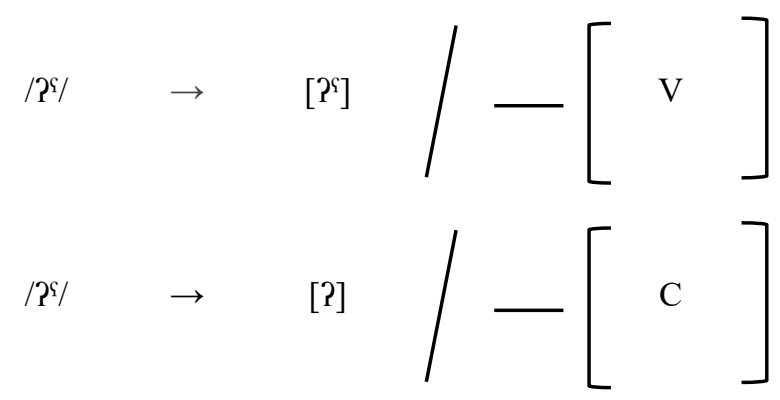

The voiceless post-alveolar pharyngealized fricative $/ \mathrm{s}^{\mathrm{q}} /$ sound was mispronounced and heard as the alveolar fricative $/ \mathrm{s} /$ in different environments, and that could be attributed to the absence of the sound from the students' mother tongue. This could lead to confusion, particularly if the sounds are used in similar words out of context as in $/$ hosn/ and $/ h \mathrm{~s}^{\varsigma} \mathrm{n} /$ having two different meanings (beauty and fort). Other examples of possible confusion mentioned earlier are /sædə/ (became a governor) and / $\mathrm{s}^{\complement} æ \mathrm{~d} ə /$ (caught 'an animal').

\subsection{Teaching and Learning Methods}

The second question of the study was intended to determine what teaching methods the teacher would use in terms of pronunciation. Their responses included repetition, audio-visual method, total and partial approaches, minimal pairs, or going eclectic. These responses were echoed in previous words by Barlow and Gierut (2002), Saben and Ingham (1991) and Oxford (2016), who emphasized repetition, listening and the use of minimal pairs. We can deduce that the teachers felt the problem and that they exerted considerable effort to help their students overcome pronunciation difficulties. The third question of the study sought to find out what learning methods the students used to improve their pronunciation. Their responses included repetition, loud reading, listening, and imitation. This also indicates that the students felt the urge to improve their pronunciation and focus on the problematic sounds. The question now did that work as the teachers and students wanted and planned?

The answer to the question above can be two-fold. First, there were noticeable efforts by the teachers to improve their students' pronunciation, and they seemed keen on that, as could be deduced from their responses. They talked about what they did, and they gave some suggestions to AFL students to practically improve their pronunciation. The students were also careful and interested in the idea of pronunciation, realizing its impotence. Although they sounded confident in their replies, they admitted that they would still work on their pronunciation. Second, the students replied to the questions orally and their responses were adequately comprehensible. Their recitations of Al-Fatiha approached perfection, which could be attributed to the imitation of model recitations in addition to the reading of this Surah in every prayer.

\section{Conclusion and Recommendations}

Mispronunciation seems to be inevitable in any $2^{\text {nd }}$ language classroom (Howatt $\&$ Widdowson, 2004). However, the study concludes that imitation of model speech in addition to repetition and loud reading can play a significant role in the improvement of pronunciation if certain conditions are met. First, repetition of single sounds, words or phrases should never turn into a mechanical drill. It must be monitored by the teacher, who is supposed to be a native speaker of Arabic or an AFL teacher with an excellent command of spoken Arabic. Second, identifying and highlighting difficult sounds must be the trend to follow, where minimal pairs are used whenever appropriate. Minimal pairs help the student to realize and determine the contrastive properties of the sounds (Barlow \& Gierut, 2002). Third, in addition to being monitored, students should listen to their pronunciation of minimal pairs critically, enhancing their sensitivity to the sound. There can also be a nonconventional treatment of minimal pairs by getting exposed to unknown pairs just to sharpen students' sensitivity and perception (Saben \& Ingham, 1991). This can reflect positively on the students' pronunciation. Fourth, going eclectic was talked about by the teachers and inadvertently referred to by the students. Therefore, we can say that using a combination of methods can help alleviate the problem and help the students to improve their pronunciation and to approach an acceptable production of the difficult sounds. This idea is supported by a study conducted by Bouchhioua (2017) on Tunisian EFL learners. She suggested that an eclectic approach can help the teacher explicitly instruct, raise students' awareness and help them interact in a meaningful context, emphasizing explicit pronunciation teaching. Therefore, the current study can contribute to the AFL teaching and learning in Saudi Arabia and other places where Arabic is 
taught to non-Arabic speaking students. The recommendations referred to in this work are directed mainly to (1) ministries of education and decision-makers, and (2) Arabic Language Institutes.

\section{References}

Asher, J. (1988). Learning another language through actions. Sky Oaks.

Bailey, K. M., \& Nunan, D. (2005). Practical English language teaching: speaking.

Barlow, J. A., \& Gierut, J. A. (2002). Minimal pair approaches to phonological remediation. Seminars in speech and language, 23(1), 57-68. https://doi.org/10.1055/s-2002-24969

Bouchhioua, N. (2017). The effects of explicit pronunciation instruction on the comprehensibility and intelligibility of Tunisian EFL learners. International Journal of Research Studies in Language Learning, 6(3), 73-88. https://doi.org/10.5861/ijrsll.2016.1480

Brazil, D., Johns, C., \& Coulthard, M. (1980). Discourse Intonation and Language Teaching. London.

Celce-Murcia, M., Brinton, D. M., \& Goodwin, J. M. (1996). Teaching pronunciation: A reference for teachers of English to speakers of other languages. Cambridge University Press.

Cenoz, J., \& Lecumberri, M. L. G. (1999). The acquisition of English pronunciation: Learners' views. International Journal of Applied Linguistics, 9(1), 3-15. https://doi.org/10.1111/j.1473-4192.1999.tb00157.x

Damiati, H. (2005). The correlation between listening skill and pronunciation accuracy: a case study in the firt year of smk vocation higt school pupita bangsa ciputat school year 2005-2006.

Gass, S. M., \& Varonis, E. M. (1989). Incorporated repairs in nonnative discourse. In Eisenstein M. R. (Ed.), The Dynamic Interlanguage. Topics in Language and Linguistics (pp. 71-86). Springer, Boston, MA. https://doi.org/10.1007/978-1-4899-0900-8_5

Hamad, H. M. (2018). Using Technology in Teaching Arabic to Nonnative Speakers. Alma'rifah, 15(1), 110-130.

Howatt, A. P. R., \& Widdowson, H. G. (2004). A history of ELT. Oxford University Press.

Jabbarova, A. (2020). THE IMPORTANCE AND PRINCIPLES OF TEACHING PRONUNCIATION TO LEARNERS. Архив Научных Публикаций JSPI, 1-4.

Jones, R. H. (1997). Beyond "listen and repeat": Pronunciation teaching materials and theories of second language acquisition. System, 25(1), 103-112. https://doi.org/10.1016/S0346-251X(96)00064-4

Krashen, S. D., Long, M. A., \& Scarcella, R. C. (1979). Age, rate and eventual attainment in second language acquisition. Tesol Quarterly, 13(4), 573-582. https://doi.org/10.2307/3586451

Krashen. (1982). Principles and practice in second language acquisition.

Mansouri, F. (2000). Grammatical markedness and information processing in the acquisition of Arabic as a second language. Lincom Europa.

McMullan, J. (1988). Finding Time for the Phonetic Alphabet. Modern English Teacher, 15(3), 9-12.

Mompean, J. A. (2015). Phonetic notation in foreign language teaching and learning: Potential advantages and learners' views. Research in Language, 13(3), 292-314. https://doi.org/10.1515/rela-2015-0026

Newton, C. (1999). Phonemic script-the pros and cons. English Teaching Professional, 12, 38-42.

Nunan, D. (2002). Listening in language learning. Methodology in language teaching: An anthology of current practice, pp. 238-241. https://doi.org/10.1017/CBO9780511667190.032

Oxford, R. L. (2016). Teaching and researching language learning strategies: Self-regulation in context, Second Edition (1st ed.). Routledge. https://doi.org/10.4324/9781315719146

Paikeday, T. M. (1993). Who needs IPA? English Today, 9(1), 38-42. https://doi.org/10.1017/S026607840000691X

Pennington, M. C. (2021). Teaching Pronunciation: The State of the Art 2021. RELC Journal, 52(1), 3-21. SAGE Publications Sage UK: London, England. https://doi.org/10.1177/00336882211002283

Renukadevi, D. (2014). The role of listening in language acquisition; the challenges \& strategies in teaching listening. International journal of education and information studies, 4(1), 59-63.

Saben, C. B., \& Ingham, J. C. (1991). The effects of minimal pairs treatment on the speech-sound production of two children with phonologic disorders. Journal of Speech, Language, and Hearing Research, 34(5), 1023-1040. https://doi.org/10.1044/jshr.3405.1023 
Tench, P. (1992). Phonetic symbols in the dictionary and in the classroom. Approaches to Pronunciation Teaching, 2(2).

Tergujeff, E. (2012). The English pronunciation teaching in Europe survey: Finland. Journal of language teaching and research, 3(4), 599-607. https://doi.org/10.4304/j1tr.3.4.599-607

Toemah, R. A. (1982). A Review of Teaching Arabic to Nonnative Speakers. Arabic Language Institute.

Wahba, K., Taha, Z. A., \& England, L. (Eds.). (2006). Handbook for Arabic language teaching professionals in the 21st century (1st ed.). Routledge. https://doi.org/10.4324/9780203824757

Yaakub, M. B. H. (2007). Teaching Arabic as a second language: An evaluation of keyword method effectiveness. Jurnal Teknologi, 46(1), 61-72.

\section{Copyrights}

Copyright for this article is retained by the author(s), with first publication rights granted to the journal.

This is an open-access article distributed under the terms and conditions of the Creative Commons Attribution license (http://creativecommons.org/licenses/by/4.0/). 